\title{
Variability of physical and chemical parameters of water from fountains in health resorts
}

\author{
Julita Milik ${ }^{1, *}$, Rafał Pasela ${ }^{1}$, and Katarzyna Budzińska $^{1}$ \\ ${ }^{1}$ University of Science and Technology in Bydgoszcz, Kaliskiego 7, 85-796 Bydgoszcz, Department \\ of Construction, Architectural and Environmental Engineering, Department of Heating, Ventilation \\ and Sanitary Engineering, Poland \\ ${ }^{2}$ Department of Animal Hygiene and Environmental Microbiology
}

\begin{abstract}
The aim of the study is to assess the quality of water from selected recreational fountains in Ciechocinek and Inowrocław health resorts. All analyzed water fountains are characterized by seasonal changes in their discharge. The exceedance of biochemical oxygen demand and chemical oxygen demand values found in the water samples may indicate water contamination with compounds of organic origin getting from the external environment to the basin of the fountain or too little recirculation of water. A significant improvement in water quality was noted in fountains in which water exchange occurred due to, for example, its failure. In addition, the water was characterized by a relatively high content of general hardness and conductivity. Reported exceedances of water quality parameters disqualify it for direct human consumption. It does not meet the requirements for drinking water. It is recommended to introduce supervision over the quality of water from fountains by the bodies of the State Sanitary Inspection in the form of water monitoring in order to eliminate from the water compounds that may have a negative impact on human health. It is recommended to regularly use pre-filtration, chlorination and sodium hypochlorite in water in fountains to eliminate physical impurities.
\end{abstract}

\section{Introduction}

City fountains are precious elements of the natural environment, they perform a decorative function and enhance attractiveness of parks all over the world. People use them to refresh, relax, interact with others and animals use them to drink water. They make up a decorative and practical element of the environment and by lowering temperature they improve the quality of air. In parks and other interesting places they are attractions frequently visited by tourists. They have a positive influence on hydrological, microclimatic, and hydrosanitary conditions, therefore should be under special protection. The authors and numerous sources report that, although it is banned, fountains are often used for bathing especially by children. Currently there are no laws that regulate investigations of this type of objects or define permissible physico- chemical parameters of water, therefore detailed studies have

\footnotetext{
*Corresponding author: julita.milik@utp.edu.pl
} 
not been conducted. Due to unlimited access to fountains they started to be treated as a pool for bathing. The main sources of water contamination include municipal and industrial wastewaters, agricultural contamination and tourist activities. Contamination of fountain water involves presence of chemical substances which have an adverse effect on the air quality and are harmful to human health. Physico-chemical threats depend on the character and level of exposure. Diseases are caused by direct presence in the proximity of fountains and inhaling a misty aerosol or consumption of the contaminated water. A health resort fountain is cleaned every day, whereas, an overall water exchange is performed only one or two times during its lifetime. Recreational fountains are equipped with disinfection filters and contaminated water circulates in a closed cycle system. Assuming that fountains are not places to be used for bathing, sanitary inspections are rarely carried out. Systems of water filtration are rarely disinfected so the circulating water is a site conductive to growth of pathogenic microorganisms posing a threat to human health. This can be caused by contamination in water reservoirs or inflitration in the pipes. Aproppriate sanitary inspection can identify the sources of threats and estimate the risks of disease connected with contact with water $[1,2]$. Tests show that fountains pose a high risk of physical and chemical nature. Fountains are potential sources of disease despite standard maintenance and use of disinfection agents. Water treatment does not guarantee prevention from dangerous diseases. On the basis of literature it can be said that occurrence of disease epidemics is quite common all over the world. Therefore, rigorous requirements and procedures concerning disinfection and filtration of water objects eg. by UV radiation or chlorine dioxide ionization need to be implemented. Preventive means need to be introduced in order to minimise the negative impact of contaminated water on human health [3-14]. The aim of the study is to analyze variability of physico-chemical parameters in fountain water situated in health resorts.

\section{Material and methods}

Tests were performed monthly from June to September 2015. They involved marking physico-chemical properties of waters coming from seven recreational fountains situated in the area of the Kujawskie anticlinorium in Ciechocinek and Inowrocław. The fountains are located in the areas of health resorts, that is parks, walkways, and graduation towers. Physico-chemical tests involved marking a set of the fountain water properties: marking of water $\mathrm{pH}$, water temperature, soluble oxygen concentration, concentration of phosphorus and total nitrogen, ammonium nitrogen, nitrate nitrogen $\mathrm{NO}_{2}, \mathrm{NO}_{3}$, general phosphorus, orthofosphorates, concentration of chlorides and biological and chemical demand for oxygen, general alkalinity, general acidity, electrical conductivity, lime hardness, general hardness, carbonate hardness, non carbonate hardness, magnesium hardness, dry residue, air temperature near fountains. For comparison, water from waterworks in Ciechocinek and Inowrocław was analyzed. The main purpose of the tests was assessment of the quality of water from selected recreational fountains situated on the territory of Ciechocinek and Inowrocław health resorts. The water for tests was taken from decorative fountains and was immediately poured into sterile bottles in order to minimise the risk of contamination of samples. Each sample of water was placed in a separate dry container made of plastics (PCV bottles) with capacity of 1.5 liters. The bottles were properly secured, marked and transported to the laboratory in thermohermetic containers covered with ice. Calibration of all devices available in the laboratory was performed before the analysis. Physico-chemical parameters of the water were marked immediately after delivering the samples to the laboratory. All markings were performed according to the methods recommended by the Polish norm, using analytic procedures described, among others, by Hermanowicz [3]. 
Table 1. The characteristics of the studied fountains.

\begin{tabular}{|c|c|c|c|c|c|c|}
\hline $\begin{array}{l}\text { Description } \\
\text { of the } \\
\text { fountain }\end{array}$ & Location & $\begin{array}{l}\text { The shape } \\
\text { of the basin }\end{array}$ & $\begin{array}{c}\text { The } \\
\text { surface of } \\
\text { the water } \\
{\left[\mathrm{m}^{2}\right]}\end{array}$ & $\begin{array}{c}\text { Depth } \\
\text { of } \\
\text { water } \\
\text { [m] }\end{array}$ & $\begin{array}{c}\text { Water } \\
\text { volume } \\
{\left[\mathrm{m}^{3}\right]}\end{array}$ & $\begin{array}{c}\text { The } \\
\text { number } \\
\text { of images }\end{array}$ \\
\hline $\begin{array}{l}\text { Grzybek } \\
\left(\mathrm{F}_{1}\right)\end{array}$ & $\begin{array}{l}\text { Ciechocinek, } \\
\text { crossing } \\
\text { Zdrojowa\&T. } \\
\text { Kościuszki } \\
\text { street }\end{array}$ & & 66.60 & 0.50 & 33.30 & one \\
\hline $\begin{array}{c}\text { Żabka } \\
\left(\mathrm{F}_{2}\right)\end{array}$ & $\begin{array}{l}\text { Ciechocinek, at } \\
\text { Spa Building }\end{array}$ & & 29.21 & 0.25 & 7.30 & three \\
\hline $\begin{array}{c}\text { Jaś i } \\
\text { Małgosia } \\
\left(\mathrm{F}_{3}\right)\end{array}$ & $\begin{array}{l}\text { Ciechocinek, } \\
\text { Spa Park }\end{array}$ & & 66.15 & 0.25 & 16.53 & two \\
\hline $\begin{array}{c}\text { Windsorf } \\
600 \\
\left(\mathrm{~F}_{4}\right)\end{array}$ & $\begin{array}{l}\text { Ciechocinek, } \\
\text { crossing } \\
\text { A. Krajowa \&A. } \\
\text { Mickiewicz } \\
\text { street }\end{array}$ & & 23.32 & 0.30 & 7.0 & four \\
\hline $\begin{array}{l}\text { Fountain } \\
\text { Skwer } \\
\text { Obrońców } \\
\text { Inowrocławi } \\
\text { a }\left(\mathrm{F}_{5}\right)\end{array}$ & $\begin{array}{l}\text { Inowrocław, } \\
\text { Skwer } \\
\text { Obrońców } \\
\text { Inowrocławia, } \\
\text { Solankowa } \\
\text { street }\end{array}$ & & 43.21 & 0.50 & 21.61 & one \\
\hline $\begin{array}{c}\text { Fountain } \\
\text { Park } \\
\text { Solankowy I } \\
\left(\mathrm{F}_{6}\right)\end{array}$ & $\begin{array}{l}\text { Inowrocław, } \\
\text { Tężnie } \\
\text { Solankowe }\end{array}$ & & 15.89 & 0.20 & 3.18 & one \\
\hline $\begin{array}{c}\text { Fountain } \\
\text { Park } \\
\text { Solankowy } \\
\text { II }\left(\mathrm{F}_{7}\right)\end{array}$ & $\begin{array}{l}\text { Inowrocław, } \\
\text { Skwer ks. A. } \\
\text { Fabianowskiego } \\
\text { surroundings of } \\
\text { the Concert } \\
\text { Shell }\end{array}$ & & 25.50 & 0.25 & 6.38 & one \\
\hline \multicolumn{7}{|c|}{$\begin{array}{l}\text { Comments: } \\
\text { - all fountains have a closed water circulation system, } \\
\text { - technology for treating water supplied with tap water }\left(\mathrm{F}_{2}, \mathrm{~F}_{3}, \mathrm{~F}_{4}, \mathrm{~F}_{5}, \mathrm{~F}_{7}\right) \text { involves the use of } \\
\text { physical processes (mechanical filtration) and chemical (correction of } \mathrm{pH} \text { with sulfuric acid and } \\
\text { disinfection with sodium hypochlorite). }\end{array}$} \\
\hline
\end{tabular}

The samples of water were hardened consistently with recommendations of PN/C04632.04 norm, whereas the remaining indexes defining the quality of water, were marked within 24 hours from the moment of the samples had been collected. In this way water samples were not stored as during the time of storage the chemical composition of the water could be changed. The $\mathrm{pH}$ reaction of samples was measured in ambient temperature with the use of $\mathrm{pH}$-meter, and electrical conductivity of the samples was measured in ambient temperature using an electric conductometer. For comparison of results the samples were also tested in the acredited laboratory. 


\section{Results and discussion}

In this article, the results of a physico-chemical analysis of recreational fountain water from Ciechocinek and Inowrocław health resorts, have been presented. Selected physicochemical indexes of water were marked in the samples. Results of the physico-chemical analysis are presented in (Tab. 2). A detailed analysis of data allowed to find out that the properties of water were characterized by variability of parameters. The water from Fountain $F_{1}$ was featured by much higher values of parameters as compared to the water from the remaining fountains (Tab. 1). The mean temperature ranged between $14^{\circ} \mathrm{C}-31^{\circ} \mathrm{C}$, respectively.

\section{The $\mathbf{p H}$ reaction}

Acidic pH (lower than 7.2) may cause corrosion of metals, plaster and concrete surfaces which get into direct contact with the water. According to the National Health and Research Council of Australia (2008), $\mathrm{pH}$ for recreational water should be in the range of 6.5-8.5 for the safety of people in contact with these water systems. The values of the water indicate an alkaline reaction; $\mathrm{pH}$ value of all the tested samples of water taken from seven fountains ranged between (7.17-9.16) which is reflected by data included in (Tab. 2). $\mathrm{pH}$ of waterworks water in Inowrocław was (7.86-8.34), and in Ciechocinek was (7.17-8.63). All water from the tested samples were found to be in the permissible range given that $\mathrm{pH}$ of recreational fountain water should be within $(6.5-8.5)$ in order to protect people who happen to be in a direct contact with the water aerosol. Physical and chemical properties of water depend on $\mathrm{pH}$ value. It was found that $\mathrm{pH}$ value in the samples collected from all the tested fountains did not differ significantly from each other. Foreign literature provides average $\mathrm{pH}$ values for five tested public fountains (7.6). Water $\mathrm{pH}$ of the fountains from Tuzla was (6.4-8.3), on the average: (8.7), whereas in Mauritius $\mathrm{pH}$ was (7.6).

\section{Dissolved oxygen (DO)}

Water from the fountains exhibited good oxygenation $\left(7.21-9.93 \mathrm{mgO}_{2} / \mathrm{dm}^{3}\right)$. Lower values were found in water characterized by a slower flow, whereas water with faster flow was more stirred and therefore more oxygenated. Higher flow rate provides the possibility to solve gases. The average value for all the samples collected from recreational fountains was $\left(9.17 \mathrm{mgO}_{2} / \mathrm{dm}^{3}\right)$. The lowest content of oxygen was found for $\mathrm{F}_{1}$, fountain and the highest for $F_{2}$ fountain, whereas, solubility of gases in water depends on their chemical composition, particle pressure, water temperature; whereas in natural water it depends on the water physio-chemical composition. Oxygen comes from the atmosphere and photosynthesis processes and occurs in water reservoirs that have contact with atmospheric air. The rate of atmospheric oxygen solubility in water is dependent on the weather conditions such as: atmospheric and hydrostatic pressure, water flow, wind and water surface waving. The content of dissolved oxygen in water is $\left(0-14.0 \mathrm{mg} \mathrm{O} \mathrm{O}_{2} / \mathrm{dm}^{3}\right)$. Dissolved oxygen is a component, which, in the presence of aggressive carbon dioxide, can increase the corrosion process of metal devices and pipes.

\section{Electrical conductivity (EC)}

Even if comparatively high electrical conductivity values were obtained for some samples, these values are less than $1000 \mathrm{mg} / \mathrm{L}$ or $1000 \mathrm{ppm}$. A conductivity value of $1000 \mathrm{mg} / \mathrm{L}$ is considered the standard by the World Health Organization (WHO). The lowest value was reported for the water from waterworks in Ciechocinek and was equal to (0.97$1.53 \mu \mathrm{S} / \mathrm{cm})$, a slightly higher value was fund for water from waterworks in Inowrocław $(1.09-1.46 \mu \mathrm{S} / \mathrm{cm})$. For the water collected from seven fountains in the health resorts the average value was $(0.85-125.4 \mu \mathrm{S} / \mathrm{cm})$. The highest value was found for fountain $\mathrm{F}_{1}:(69.55-117.50 \mu \mathrm{S} / \mathrm{cm})$ and fountain $\mathrm{F}_{7}:(58.31-125.40 \mu \mathrm{S} / \mathrm{cm})$. Whereas, high values of electrical conductivity indicate salinity, problems with water contamination in the water samples. For comparison, in five analyzed fountains in Mauritius, electrical conductivity 
was found to be (111.7-376.6 $\mu \mathrm{S} / \mathrm{cm})$, whereas in Tuzla electrical conductivity of the water collected from 5 fountains was at the level $(220 \mu \mathrm{S} / \mathrm{cm})$ [7,9]. For comparison, 5 samples with water (water from public showers) were examined and its conductivity was found to be $(341.62 \mu \mathrm{S} / \mathrm{cm})$.

Table 2. The results of water quality analyses of fountains located in Ciechocinek.

\begin{tabular}{|c|c|c|c|c|c|c|}
\hline Parameter & Unit & $\mathbf{F}_{1}$ & $\mathbf{F}_{2}$ & $F_{3}$ & $\mathbf{F}_{4}$ & $\begin{array}{c}\text { Tap water } \\
\text { Ciechocinek }\end{array}$ \\
\hline Temperature & ${ }^{\circ} \mathrm{C}$ & $\begin{array}{c}14.00 \\
-26.10\end{array}$ & $\begin{array}{c}15.00 \\
-25.40\end{array}$ & $\begin{array}{c}16.00 \\
-31.00\end{array}$ & $\begin{array}{c}15.00 \\
-25.00\end{array}$ & $\begin{array}{c}8.00 \\
-12.00\end{array}$ \\
\hline $\mathrm{pH}$ & - & $\begin{array}{c}8.00 \\
-8.69\end{array}$ & $\begin{array}{c}7.78 \\
-8.80\end{array}$ & $\begin{array}{c}7.99 \\
-9.13 \\
\end{array}$ & $\begin{array}{c}7.97 \\
-9.08\end{array}$ & $\begin{array}{c}7.17 \\
-8.63 \\
\end{array}$ \\
\hline $\begin{array}{c}\text { Electrical } \\
\text { conductivity }\end{array}$ & $\mu \mathrm{S} / \mathrm{cm}$ & $\begin{array}{c}69.55 \\
-117.50 \\
\end{array}$ & $\begin{array}{c}1.01 \\
-2.78 \\
\end{array}$ & $\begin{array}{c}0.85 \\
-2.15 \\
\end{array}$ & $\begin{array}{c}1.78 \\
-2.60 \\
\end{array}$ & $\begin{array}{c}0.97 \\
-1.53 \\
\end{array}$ \\
\hline $\begin{array}{c}\text { Dissolved } \\
\text { oxygen }\end{array}$ & $\mathrm{mgO}_{2} / \mathrm{dm}^{3}$ & $\begin{array}{c}6.80 \\
-7.90 \\
\end{array}$ & $\begin{array}{c}9.40 \\
-10.70 \\
\end{array}$ & $\begin{array}{c}8.30 \\
-10.40 \\
\end{array}$ & $\begin{array}{c}8.80 \\
-10.40 \\
\end{array}$ & not found \\
\hline $\begin{array}{c}\text { Basic } \\
\text { alkalinity }\end{array}$ & $\mathrm{mval} / \mathrm{dm}^{3}$ & $\begin{array}{c}2.90 \\
-8.50\end{array}$ & $\begin{array}{c}3.80 \\
-6.90\end{array}$ & $\begin{array}{c}3.00 \\
-5.00\end{array}$ & $\begin{array}{c}4.20 \\
-8.40\end{array}$ & $\begin{array}{c}4.10 \\
-6.90\end{array}$ \\
\hline $\begin{array}{c}\text { Biochemical } \\
\text { oxygen }\end{array}$ & $\mathrm{mgO}_{2} / \mathrm{dm}^{3}$ & $\begin{array}{c}5.45 \\
-72.72 \\
\end{array}$ & $\begin{array}{c}4.30 \\
-22.50\end{array}$ & $\begin{array}{c}4.20 \\
-11.51\end{array}$ & $\begin{array}{c}2.50 \\
-5.95 \\
\end{array}$ & $\begin{array}{c}1.25 \\
-2.90 \\
\end{array}$ \\
\hline $\begin{array}{c}\text { Chemical } \\
\text { oxygen }\end{array}$ & $\mathrm{mgO}_{2} / \mathrm{dm}^{3}$ & $\begin{array}{c}5419.52 \\
-17006.00 \\
\end{array}$ & $\begin{array}{c}87.83 \\
-177.54 \\
\end{array}$ & $\begin{array}{c}54.20 \\
-147.60 \\
\end{array}$ & $\begin{array}{c}101.80 \\
-149.40 \\
\end{array}$ & $\begin{array}{c}21.32 \\
-28.72 \\
\end{array}$ \\
\hline Chlorides & $\mathrm{mgCl} / \mathrm{dm}^{3}$ & $\begin{array}{c}30500.00 \\
-45000.00 \\
\end{array}$ & $\begin{array}{c}125.00 \\
-795.00 \\
\end{array}$ & $\begin{array}{c}187.50 \\
-425.00 \\
\end{array}$ & $\begin{array}{c}110.00 \\
-585.00 \\
\end{array}$ & $\begin{array}{c}150.00 \\
-405.00 \\
\end{array}$ \\
\hline $\begin{array}{c}\text { Amonium } \\
\text { ions }\end{array}$ & $\mathrm{mgNH}_{4}{ }^{+} / \mathrm{dm}^{3}$ & $\begin{array}{c}3.90 \\
-6.70\end{array}$ & $\begin{array}{c}0.15 \\
-0.55\end{array}$ & $\begin{array}{c}0.13 \\
-1.45\end{array}$ & $\begin{array}{c}0.05 \\
-0.73\end{array}$ & not found \\
\hline $\begin{array}{c}\text { Nitrite } \\
\text { nitrogen }\end{array}$ & $\mathrm{mgNO}_{2}-/ \mathrm{dm}^{3}$ & $\begin{array}{c}0.01 \\
-0.15\end{array}$ & $\begin{array}{c}0.01 \\
-0.65\end{array}$ & $\begin{array}{c}0.01 \\
-0.15\end{array}$ & $\begin{array}{c}0.07 \\
-0.34\end{array}$ & not found \\
\hline $\begin{array}{c}\text { Nitrate } \\
\text { nitrogen }\end{array}$ & $\mathrm{mgNO}_{3}{ }^{-} / \mathrm{dm}^{3}$ & $\begin{array}{c}0.50 \\
-1.25 \\
\end{array}$ & $\begin{array}{c}2.49 \\
-11.75\end{array}$ & $\begin{array}{c}1.98 \\
-6.65 \\
\end{array}$ & $\begin{array}{c}2.77 \\
-7.48 \\
\end{array}$ & $\begin{array}{c}2.17 \\
-3.69 \\
\end{array}$ \\
\hline $\begin{array}{c}\text { Total } \\
\text { hardness }\end{array}$ & $\mathrm{mg} \mathrm{CaCO}_{3}$ & $\begin{array}{c}7857.00 \\
-9910.50 \\
\end{array}$ & $\begin{array}{c}400.00 \\
-832.00 \\
\end{array}$ & $\begin{array}{c}393.00 \\
-521.50 \\
\end{array}$ & $\begin{array}{c}335.00 \\
-818.00 \\
\end{array}$ & $\begin{array}{c}495.00 \\
-578.60 \\
\end{array}$ \\
\hline $\begin{array}{l}\text { Calcium } \\
\text { hardness }\end{array}$ & $\mathrm{mgCa} / \mathrm{dm}^{3}$ & $\begin{array}{c}255.00 \\
-821.00\end{array}$ & $\begin{array}{c}11.43 \\
-22.00\end{array}$ & $\begin{array}{c}14.40 \\
-23.30\end{array}$ & $\begin{array}{c}9.20 \\
-18.00\end{array}$ & $\begin{array}{c}14.00 \\
-26.50\end{array}$ \\
\hline $\begin{array}{l}\text { Carbonate } \\
\text { hardness }\end{array}$ & $\mathrm{mval} / \mathrm{dm}^{3}$ & $\begin{array}{c}2.50 \\
-8.50\end{array}$ & $\begin{array}{c}3.30 \\
-6.90\end{array}$ & $\begin{array}{c}3.30 \\
-4.20\end{array}$ & $\begin{array}{c}3.50 \\
-7.40\end{array}$ & $\begin{array}{c}4.00 \\
-6.40\end{array}$ \\
\hline $\begin{array}{c}\text { Non- } \\
\text { carbonate }\end{array}$ & $\mathrm{mval} / \mathrm{dm}^{3}$ & $\begin{array}{c}153.14 \\
-195.71 \\
\end{array}$ & $\begin{array}{c}4.30 \\
-9.74\end{array}$ & $\begin{array}{c}4.30 \\
-9.56\end{array}$ & $\begin{array}{c}0.74 \\
-7.32 \\
\end{array}$ & $\begin{array}{c}3.64 \\
-6.29 \\
\end{array}$ \\
\hline $\begin{array}{l}\text { Magnesium } \\
\text { hardness }\end{array}$ & $\mathrm{mval} / \mathrm{dm}^{3}$ & $\begin{array}{c}66.43 \\
-116.07\end{array}$ & $\begin{array}{c}3.43 \\
-76.29\end{array}$ & $\begin{array}{c}2.14 \\
-5.14\end{array}$ & $\begin{array}{c}2.25 \\
-8.79\end{array}$ & $\begin{array}{c}0.46 \\
-3.75\end{array}$ \\
\hline
\end{tabular}

\section{Total hardness}

Hardness of drinking water cannot exceed $\left(500 \mathrm{mg} \mathrm{CaCO}_{3}\right)$ [WHO]. Soft water should oscillate between $(0-50 \mathrm{mg} \mathrm{CaCO} 3)$, hard water from (121-180 $\left.\mathrm{mg} \mathrm{CaCO}_{3}\right)$, whereas very hard water $>180 \mathrm{mg} \mathrm{CaCO}_{3}[1,2]$. The highest total hardness was found in fountain $\mathrm{F}_{1}$, and the lowest in $\mathrm{F}_{5}$. The average value of the collected samples was $\left(392.96 \mathrm{mg} \mathrm{CaCO}_{3}\right.$ ) (Tab. 2). Softness or hardness of water has been classified as follow in (Tab. 2) and (Tab. 3). Total hardness of water in the city of Hamadan was: $(66.12 \mathrm{mg} \mathrm{CaCO} 3)$, whereas in Tuzla (57.60-280 $\left.\mathrm{mg} \mathrm{CaCO}_{3}\right)[4,6]$.

Table 3. The results of water quality analyses of fountains located in Inowrocław. 


\begin{tabular}{|c|c|c|c|c|c|}
\hline Parameter & Unit & $\mathbf{F}_{5}$ & $F_{6}$ & $\mathbf{F}_{7}$ & $\begin{array}{c}\text { Tap water } \\
\text { Inowroclaw }\end{array}$ \\
\hline Temperature & ${ }^{\circ} \mathrm{C}$ & $\begin{array}{c}14.00 \\
-25.00 \\
\end{array}$ & $\begin{array}{c}16.00 \\
-22.00 \\
\end{array}$ & $\begin{array}{c}14.00 \\
-30.00 \\
\end{array}$ & $\begin{array}{c}9.00 \\
-11.00 \\
\end{array}$ \\
\hline $\mathrm{pH}$ & - & $\begin{array}{r}7.60 \\
-8.81 \\
\end{array}$ & $\begin{array}{r}7.87 \\
-8.96 \\
\end{array}$ & $\begin{array}{c}8.28 \\
-9.16 \\
\end{array}$ & $\begin{array}{r}7.86 \\
-8.34 \\
\end{array}$ \\
\hline $\begin{array}{c}\text { Electrical } \\
\text { conductivity }\end{array}$ & $\mu \mathrm{S} / \mathrm{cm}$ & $\begin{array}{c}1.60 \\
-2.98 \\
\end{array}$ & $\begin{array}{c}1.01 \\
-2.10 \\
\end{array}$ & $\begin{array}{c}58.31 \\
-125.40 \\
\end{array}$ & $\begin{array}{c}1.09 \\
-1.46 \\
\end{array}$ \\
\hline $\begin{array}{c}\text { Dissolved } \\
\text { oxygen }\end{array}$ & $\mathrm{mgO}_{2} / \mathrm{dm}^{3}$ & $\begin{array}{c}8.10 \\
-12.60 \\
\end{array}$ & $\begin{array}{c}9.00 \\
-10.00 \\
\end{array}$ & $\begin{array}{c}6.10 \\
-12.00 \\
\end{array}$ & not found \\
\hline $\begin{array}{c}\text { Basic } \\
\text { alkalinity }\end{array}$ & $\mathrm{mval} / \mathrm{dm}^{3}$ & $\begin{array}{c}1.10 \\
-7.60 \\
\end{array}$ & $\begin{array}{c}0,56 \\
-3.80 \\
\end{array}$ & $\begin{array}{c}4.00 \\
-8.66 \\
\end{array}$ & $\begin{array}{c}7.10 \\
-9.00 \\
\end{array}$ \\
\hline $\begin{array}{c}\text { Biochemical } \\
\text { oxygen }\end{array}$ & $\mathrm{mgO}_{2} / \mathrm{dm}^{3}$ & $\begin{array}{c}2.45 \\
-5.00 \\
\end{array}$ & $\begin{array}{c}2.50 \\
-5.96 \\
\end{array}$ & $\begin{array}{c}4.35 \\
-5.20 \\
\end{array}$ & $\begin{array}{c}1.40 \\
-2.20 \\
\end{array}$ \\
\hline $\begin{array}{c}\text { Chemical } \\
\text { oxygen }\end{array}$ & $\mathrm{mgO}_{2} / \mathrm{dm}^{3}$ & $\begin{array}{c}11.00 \\
-55.80\end{array}$ & $\begin{array}{c}15.10 \\
-69.10\end{array}$ & $\begin{array}{c}12.50 \\
-66.60\end{array}$ & $\begin{array}{c}15.00 \\
-24.10\end{array}$ \\
\hline Chlorides & $\mathrm{mgCl} / \mathrm{dm}^{3}$ & $\begin{array}{c}100.00 \\
-250.00\end{array}$ & $\begin{array}{c}75.00 \\
-240.00 \\
\end{array}$ & $\begin{array}{c}21.25 \\
-47.00 \\
\end{array}$ & $\begin{array}{c}50.00 \\
-185.00 \\
\end{array}$ \\
\hline $\begin{array}{l}\text { Amonium } \\
\text { ions }\end{array}$ & $\mathrm{mgNH}_{4}+/ \mathrm{dm}^{3}$ & $\begin{array}{c}0.11 \\
-0.86 \\
\end{array}$ & $\begin{array}{c}0.08 \\
-0.27 \\
\end{array}$ & $\begin{array}{c}0.10 \\
-6.00 \\
\end{array}$ & $\begin{array}{c}0.09 \\
-0.12 \\
\end{array}$ \\
\hline $\begin{array}{c}\text { Nitrite } \\
\text { nitrogen }\end{array}$ & $\mathrm{mgNO}_{2}-/ \mathrm{dm}^{3}$ & $\begin{array}{c}0.01 \\
-0.12 \\
\end{array}$ & $\begin{array}{c}0.01 \\
-0.04 \\
\end{array}$ & $\begin{array}{c}0.01 \\
-0.21 \\
\end{array}$ & not found \\
\hline $\begin{array}{c}\text { Nitrate } \\
\text { nitrogen }\end{array}$ & $\mathrm{mgNO}_{3}{ }^{-} / \mathrm{dm}^{3}$ & $\begin{array}{c}0.45 \\
-0.79 \\
\end{array}$ & $\begin{array}{c}0.36 \\
-0.94 \\
\end{array}$ & $\begin{array}{c}0.20 \\
-0.50 \\
\end{array}$ & $\begin{array}{c}0.50 \\
-0.67 \\
\end{array}$ \\
\hline $\begin{array}{c}\text { Total } \\
\text { hardness }\end{array}$ & $\mathrm{mgCaCO}_{3}$ & $\begin{array}{c}2.50 \\
-39.00 \\
\end{array}$ & $\begin{array}{c}300.20 \\
-950.00 \\
\end{array}$ & $\begin{array}{c}100.00 \\
-625.00\end{array}$ & $\begin{array}{c}16.07 \\
-718.00 \\
\end{array}$ \\
\hline $\begin{array}{l}\text { Calcium } \\
\text { hardness }\end{array}$ & $\mathrm{mgCa} / \mathrm{dm}^{3}$ & $\begin{array}{c}4.00 \\
-19.80 \\
\end{array}$ & $\begin{array}{c}7.00 \\
-26.40 \\
\end{array}$ & $\begin{array}{c}17.89 \\
-58.00 \\
\end{array}$ & $\begin{array}{c}9.21 \\
-31.60 \\
\end{array}$ \\
\hline $\begin{array}{l}\text { Carbonate } \\
\text { hardness }\end{array}$ & $\mathrm{mval} / \mathrm{dm}^{3}$ & $\begin{array}{c}1.00 \\
-6.80\end{array}$ & $\begin{array}{c}2.60 \\
-3.80\end{array}$ & $\begin{array}{c}3.40 \\
-7.40\end{array}$ & $\begin{array}{c}7.20 \\
-9.00\end{array}$ \\
\hline $\begin{array}{c}\text { Non- } \\
\text { carbonate }\end{array}$ & $\mathrm{mval} / \mathrm{dm}^{3}$ & $\begin{array}{c}0.70 \\
-10.93 \\
\end{array}$ & $\begin{array}{c}6.23 \\
-15.50 \\
\end{array}$ & $\begin{array}{c}19.20 \\
-37.60 \\
\end{array}$ & $\begin{array}{c}4.90 \\
-8.87 \\
\end{array}$ \\
\hline $\begin{array}{l}\text { Magnesium } \\
\text { hardness }\end{array}$ & $\mathrm{mval} / \mathrm{dm}^{3}$ & $\begin{array}{c}3.00 \\
-13.60\end{array}$ & $\begin{array}{c}10.20 \\
-19.50\end{array}$ & $\begin{array}{c}26.00 \\
-87.00\end{array}$ & $\begin{array}{c}11.20 \\
-15.50\end{array}$ \\
\hline
\end{tabular}

\section{Carbonate hardness}

Carbonate hardness of the analyzed water was: $\left(4.33 \mathrm{mval} / \mathrm{dm}^{3}\right)$. All the samples were characterized by similar values from (1.00-9.00 mval/ $\mathrm{dm}^{3}$ ) (Tab. 2). Slightly higher values than for the water from city fountains was observed for the water from Inowrocław waterworks: (7.20-9.00 mval/ $\left.\mathrm{dm}^{3}\right)$ and Ciechocinek: $\left(4.00-6.40 \mathrm{mval} / \mathrm{dm}^{3}\right)$.

\section{Non-Carbonate hardness}

The highest value was found for $F_{1}$ : (153.14-195.71 mval $\left./ \mathrm{dm}^{3}\right)$, the remaining values were much lower but similar to each other ranging from $\left(3.05-31.75 \mathrm{mval} / \mathrm{dm}^{3}\right)$. Non carbonate hardness was at the level from (42.00-242.60 $\left.\mathrm{mval} / \mathrm{dm}^{3}\right)$ [7].

\section{Calcium hardness}

The highest value was found in $F_{1}$ : $\left(255.00-821.00 \mathrm{mgCa} / \mathrm{dm}^{3}\right)$ and $F_{2}$ : (11.43-22.00 $\left.\mathrm{mgCa} / \mathrm{dm}^{3}\right)$, the remaining fountains were characterized by a relatively low values between $\left(10.68\right.$ and $\left.41.58 \mathrm{mgCa} / \mathrm{dm}^{3}\right)$, water from the waterworks contained $\left(21.22-19.65 \mathrm{mgCa} / \mathrm{dm}^{3}\right)$. The mean value of the analyzed water was $\left(90.43 \mathrm{mgCa} / \mathrm{dm}^{3}\right)$, that is, much less, as compared to the analyzed water from the fountains in Hamadan $\left(249.7 \mathrm{mgCa} / \mathrm{dm}^{3}\right)$ [4].

\section{Nitrite nitrogen, $\mathrm{NO}_{2}-\mathrm{N}$}


Concentration of nitrite nitrogen in 7 fountains was from $\left(0.02-11.75 \mathrm{mgNO}_{2}{ }^{-} / \mathrm{dm}^{3}\right)$, with average content: $\left(0.1 \mathrm{mgNO}_{2}^{-} / \mathrm{dm}^{3}\right)$ (Tab. 2). In the waterworks water of Inowrocław and Ciechocinek nitrite nitrogen not found, (Tab. 3). In Tuzla the content of nitrites in the water was insignificant $\left(0.004-0.006 \mathrm{mgNO}_{2}^{-} / \mathrm{dm}^{3}\right)$ [7].

\section{Nitrates (nitrate nitrogen)}

In the case of high concentration of nitrates and nitrites, total exchange and treatment of water in a reservoir are recommended. The content of nitrate nitro $\mathrm{mgNH}_{4}+\mathrm{dm}^{3}$ gen in the water from all the seven fountains reached the mean value of $\left(2.35 \mathrm{mgNO}_{3}{ }^{-} / \mathrm{dm}^{3}\right)$, the lowest value was observed in $\mathrm{F}_{7}:\left(0.20-0.50 \mathrm{mgNO}_{3}{ }^{-} / \mathrm{dm}^{3}\right)$, whereas the highest content of nitrates was discovered in $\mathrm{F}_{4}:\left(2.77-7.48 \mathrm{mgNO}_{3}{ }^{-} / \mathrm{dm}^{3}\right)$. Recreational fountains in Tuzla were featured by a similar value range $\left(1.1-6.1 \mathrm{mgNO}_{3}{ }^{-} / \mathrm{dm}^{3}\right)$.

\section{Ammonium ions (ammonium nitrogen)}

Concentration of ammonium nitrogen in the water of seven fountains was between $\left(0.05-0.73\right.$ and $\left.3.90-6.70 \mathrm{mgNH}_{4}^{+} / \mathrm{dm}^{3}\right)$ with the mean value of $\left(1.27 \mathrm{mgNH}_{4}^{+} / \mathrm{dm}^{3}\right)$. Waterworks water indicated lower values than that of the analyzed fountains being, respectively: $\left(0.05\right.$ and $\left.0.08 \mathrm{mgNH}_{4}{ }^{+} / \mathrm{dm}^{3}\right)$. In Tuzla the parameter ranged from $\left(0.04-1.24 \mathrm{mgNH}_{4}^{+} / \mathrm{dm}^{3}\right)$ [7].

\section{Phosphates (general phosphorus)}

In three samples of the examined fountains no traces of the element $\left(F_{5}, F_{6}, F_{7}\right)$, were detected. In the remaining fountains $\left(0.02-0.68 \mathrm{mgP} / \mathrm{dm}^{3}\right)$ were found. In the waterworks water in Inowrocław no phosphates were found, whereas in Ciechocinek very slight traces of phosphates were detected $\left(0.06 \mathrm{mgP} / \mathrm{dm}^{3}\right)$.

\section{Chlorides}

In the tested samples with fountain water, values ranged from $\left(21.25-47.00 \mathrm{mgCl} / \mathrm{dm}^{3}\right)$ to $\left(30500.00-45000.00 \mathrm{mgCl} / \mathrm{dm}^{3}\right)$, with average content: $\left(321.52 \mathrm{mgCl} / \mathrm{dm}^{3}\right)$, for the waterworks water of Inowrocław (Tab. 3) it was $\left(50.00-185.00 \mathrm{mgCl} / \mathrm{dm}^{3}\right)$, whereas for Ciechocinek it was $\left(150.00-405.00 \mathrm{mgCl} / \mathrm{dm}^{3}\right)$ [1]. In the $\mathrm{F}_{1}$ fountain, a significant excess of chloride values from $\left(30500.00-45000.00 \mathrm{mgCl} / \mathrm{dm}^{3}\right)$ has been observed. In Tuzla the concentration of chlorides was at the level of $\left(12.00-21.00 \mathrm{mgCl} / \mathrm{dm}^{3}\right)$ indicating significant differences [7].

\section{Basic alkalinity}

This parameter in the analyzed water was from $\left(0.56-3.80 \mathrm{mgCl} / \mathrm{dm}^{3}\right)$ and $(4.00-8.66$ $\left.\mathrm{mgCl} / \mathrm{dm}^{3}\right)$, with the average content equal to $\left(4.73 \mathrm{mgCl} / \mathrm{dm}^{3}\right)$.

\section{Chemical oxygen demand}

The chemical oxygen demand test can be used to easily quantify the amount of organics in water. The most common application of chemical oxygen demand is in quantifying the amount of oxidizable pollutants found in surface water (e.g. lakes and rivers) or wastewater. Chemical oxygen demand is useful in terms of water quality by providing a metric to determine the effect an effluent will have on the receiving body, much like biochemical oxygen demand biochemical oxygen demand.

The highest concentration of the parameter was observed in the fountain $\mathrm{F}_{1}$ and it was equal to $\left(5419.52-17000.00 \mathrm{mgO}_{2} / \mathrm{dm}^{3}\right)$ for the examined samples.

\section{Biochemical oxygen demand}

Among the seven discussed fountains, the highest value was observed for $\mathrm{F}_{1}$ : (5.45-72.72 $\left.\mathrm{mgO}_{2} / \mathrm{dm}^{3}\right)$, the remaining ones being significantly lower for example $(2.50-5.95$ $\left.\mathrm{mgO}_{2} / \mathrm{dm}^{3}\right)$ in fountain $\mathrm{F}_{4}$. The mean value was: $\left(62.5 \mathrm{mgO}_{2} / \mathrm{dm}^{3}\right)$ for the seven fountains. The concentration of biological oxygen demand features in the waterworks water was (1.40-2.20 $\left.\mathrm{mg} \mathrm{O}_{2} / \mathrm{dm}^{3}\right)$ in Inowrocław and (1.25-2.90 $\mathrm{mgO}_{2} / \mathrm{dm}^{3}$ ) Ciechocinek.

\section{General acidity}


In six of the analyzed fountains no parameter was found, whereas, in $\mathrm{F}_{5}$ it reached the level of $\left(0.2 \mathrm{mval} / \mathrm{dm}^{3}\right)$. Similar values were observed for water from Inowrocław waterworks in the amount: $\left(0.24 \mathrm{mval} / \mathrm{dm}^{3}\right)$ and in Ciechocinek $\left(0.25 \mathrm{mval} / \mathrm{dm}^{3}\right)$ (Tab. 2).

\section{Magnesium hardness}

The lowest magnesium hardness was detected in $\mathrm{F}_{3}:\left(2.14-5.14 \mathrm{mval} / \mathrm{dm}^{3}\right)$, whereas, in $F_{1}:\left(66.43-116.07 \mathrm{mval} / \mathrm{dm}^{3}\right)$ it was much higher with the average of $\left(111.38 \mathrm{mval} / \mathrm{dm}^{3}\right)$. Both fountains were characterized by high variability of parameters.

\section{Conclusions}

The paper presents the results of research on selected physico-chemical parameters of water from fountains occurring in the cities of Ciechocinek and Inowrocław. Analysis of the results showed the variability of the water quality parameters in the four-month research period. The exceedance of biochemical oxygen demand and chemical oxygen demand values found in the water samples may indicate water contamination with compounds of organic origin getting from the external environment to the basin of the fountain or too little recirculation of water. A significant improvement in water quality was noted in fountains in which water exchange occurred due to, for example, its failure. In addition, the water was characterized by a relatively high content of general hardness and conductivity. Reported exceedances of water quality parameters disqualify it for direct human consumption. It does not meet the requirements for drinking water. It is recommended to introduce supervision over the quality of water from fountains by the bodies of the State Sanitary Inspection in the form of water monitoring in order to eliminate from the water compounds that may have a negative impact on human health.

\section{References}

1. Dz. U. 2000.82.937. Regulation of the Minister of Health of 4 September, (2000)

2. WHO, Water sampling and analysis. Guidelines for drinking water quality. World Health Organization, (2008)

3. Gumus, M. Karatas, C. Akkoz, Jour. of App. Biol. Sc. (2017)

4. Hermanowicz at all. Physico-chemical examination of water and sewage (1999)

5. Feyzimanesh, Cheraghi M, Vafaei H. Jour. of Ren. Nat. Res. Bhutan, 3(1), 40-45 (2015)

6. D. Bora et. al. Journal of Envir. Prot. and Ec. 18(2): 757-763 (2017)

7. S. M. Sanches at all. Ambiente\&Agua-An Int. Jour. of App. Sc, (2015)

8. Sestan et. al. 15 th Internat. Res./Expert Conf, (2011)

9. B. Lukubye, M. Andama. Journ. of Wat. Res. and Prot. 9(7): 707-722 (2017)

10. S. Heerah, H. Neetoo. Int. J. Curr. Mic. App. Sci. 5(2): 161-172 (2016)

11. R. Illogon et. al., 4(11), 49-53 (2017)

12. Cech I. et al. South Med J. 2006 Feb; 99(2):137-42 (2006)

13. N. Wilson, L. Signal, G. Thomson. Aust. and New Zeal. Jour. of Pub. Health (2017)

14. K. Budzińska, R. Pasela et al. ROS, Ann. Set the Envir. Protec. 19, 181-199 (2017) 